\title{
LOCATIONAL STRUCTURE OF ARCHAEOLOGICAL UNDERGROUND STORAGE PITS IN NORTHWEST CÓRDOBA, ARGENTINA
}

\author{
Andrés G. Laguens*
}

\begin{abstract}
LAGUENS A. G. Locational structure of archaeological undenground storage pits in Northwest Córdoba, Argentina. Revista do Museu de Arqueologia e Etnologia, S. Paulo, 3: 17-33, 1993.
\end{abstract}

RESUMO: Este artigo fornece resultados de uma análise espacial intrasítio de traços de terra de subsolo calcinada em um sítio pré-hispânico na Argentina central: El Ranchito, datado entre 1000 a.C. e 1600 d.C. Os traços são conhecidos localmente como botijas e são registrados no sítio como três áreas de concentração apresentando uma distribuição não aleatória incluindo entre 100 e 120 botijas cada área. Dentro delas é registrada uma distribuição aleatória.

O estudo foi desenvolvido para estimar sua localização intencional como área de estocagem dentro do sítio. Postula-se que esta estratégia de estocagem tenha sido adotada como uma solução para um número de problemas paralelos, sobretudo, população em expansão e flutuações ambientais. Durante a conquista espanhola (séc. XVI), esta estratégia teria também sido implementada como resposta ao choque cultural e econômico causado pela apropriação de terra e recursos.

UNITERMOS: Análise espacial - Sítios de estocagem - Arqueologia argentina.

This paper leads with the intra-site locational analysis of storage pits at an archaeological site in an attempt to evaluate their intentional location and design.

According to the concept of locational structure as the non-random or reiterative allocation of structures to particular places within sites (Clarke 1972) we think that what we nowadays record as their intra-site location could reflect a previous design and explicit choice of a specific place, among others, as activity areas within the settlement. Those areas should have been addressed to store vegetable stuffs as implementation of a system survival strategy

(*) Universidad Nacional de Córdoba. Córdoba, Argentina during a critical period that began approximately at 1500 A.D. which was characterized, as we will see later, by the conjunction of internal and external stresses acting on the cultural system as a whole and which ultimately promoted its reorganization.

In order to accomplish the research goal we first make an exploratory statistical analysis of the spatial distribution of the features using Nearest Neighbor Analysis at an intra-site scale, and then we try to explain its pattern in terms of two possible processes: one, a functional explanation of the site within a regional organization of settlement space, and the other, an economic explanation of a strategic choice of the system within the frame of risk avoidance. 


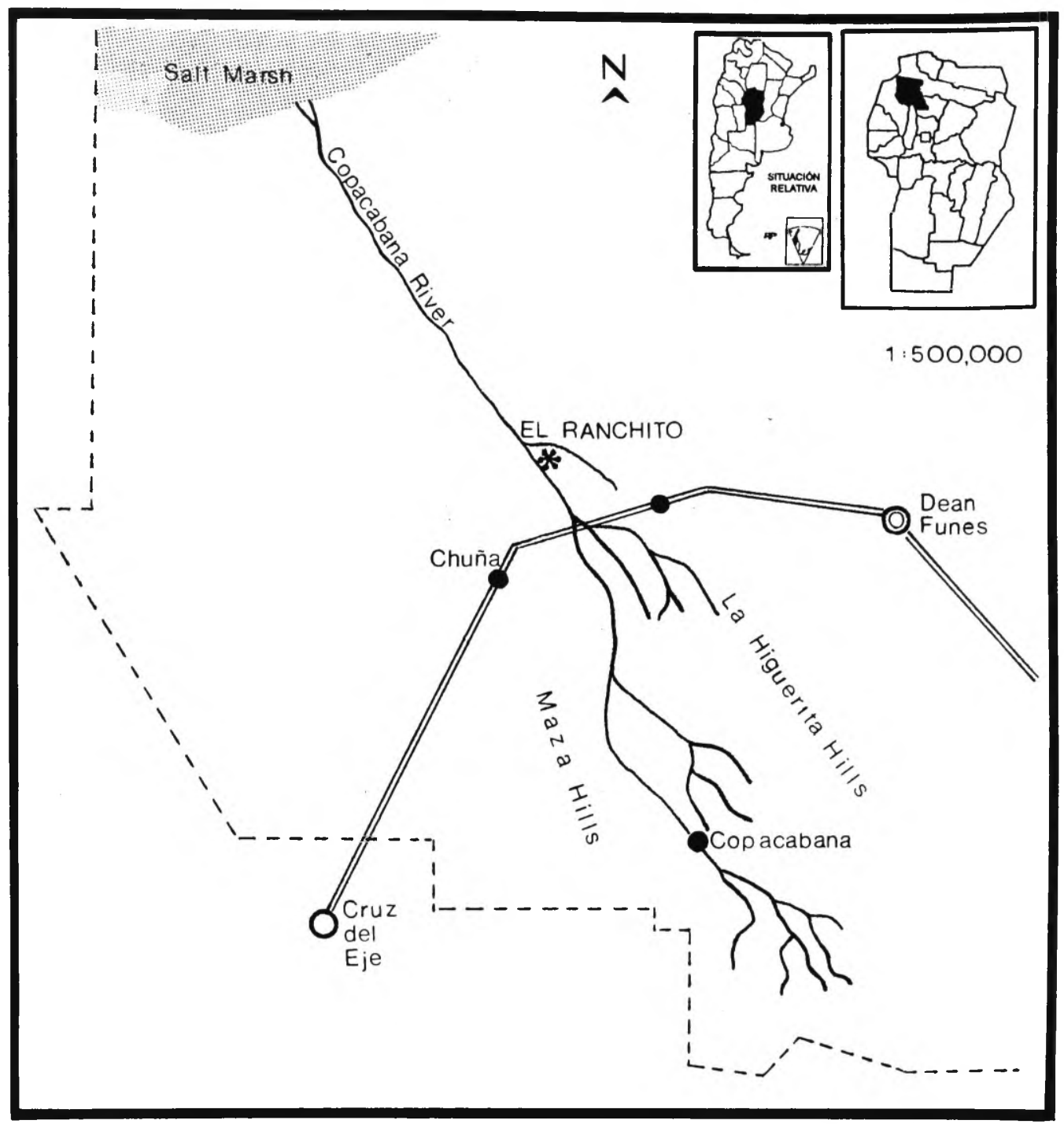

Fig. 1 - Map of Copacabana Basin and El Ranchito site. Insets show the location of the valley in Córdoba, Argentina.

\section{Contextual data}

The features under analysis were recorded at the archaeological site of El Ranchito, in the Copacabana basin, Cordoba province, Argentina. The site is situated on a currently arid to semi-arid plain where a brook, arroyo, meets a perennial river, the Copacabana, coming from the hills to the $\mathrm{SE}$ and draining NW at a large saline marsh (Fig. 1).

El Ranchito was continuously occupied from 3000 B.P. ( $2950 \pm 180$ radiocarbon years) to the
Spanish Conquest, as attested by a spindle whorl made of Spanish crockery and an indigenous artifact made on a horse bone. The features under analysis belong to the latest occupation of the site; a charcoal sample coming from one feature yielded a radiocarbon date of $370 \pm 45$ y.b.p. (1580 A.D.).

At three different places within the site (Fig. 2) we recorded subterranean features (known as botijas) with burned earth walls with a truncated conical shape, 70 to $80 \mathrm{~cm}$ deep and with 


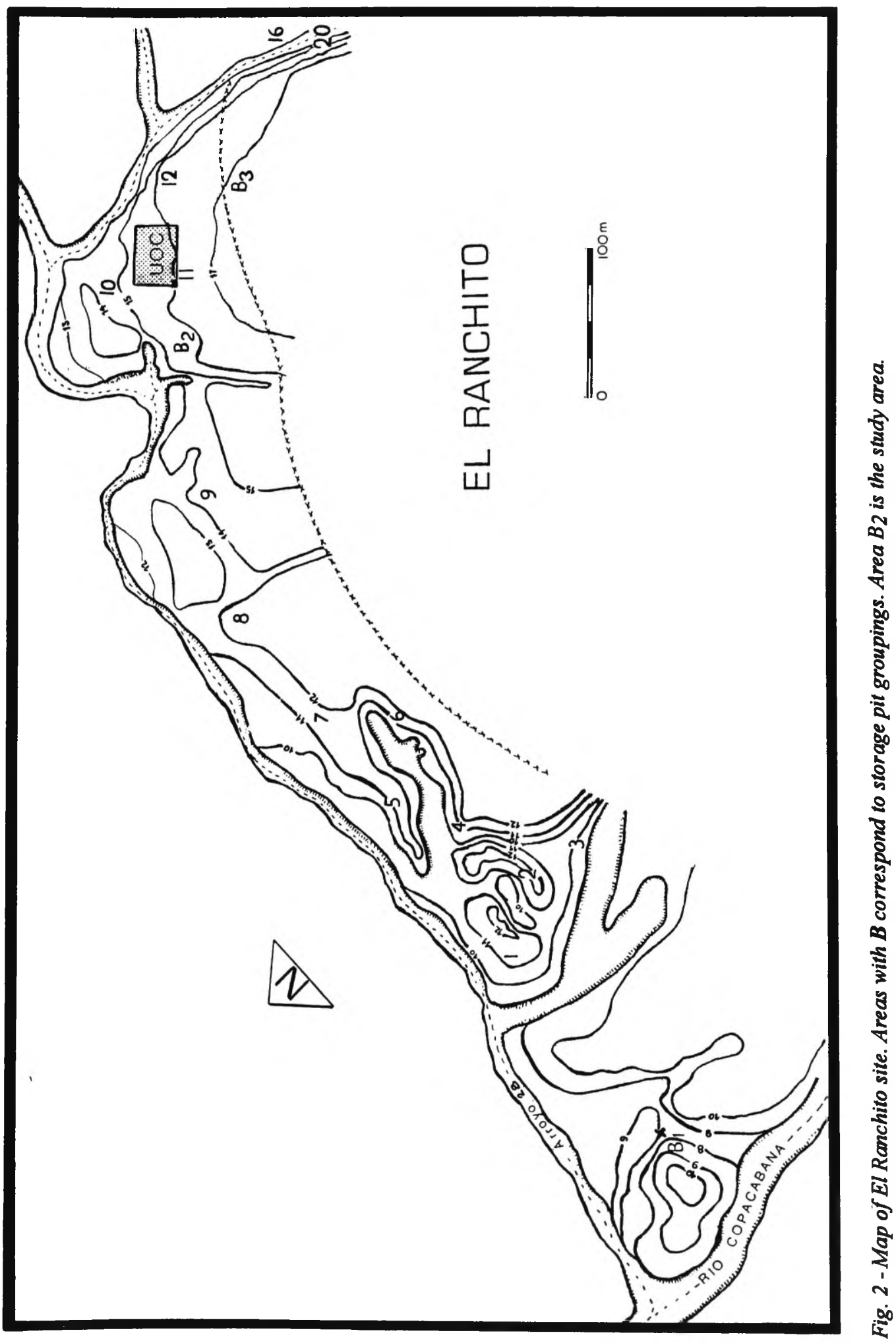


LAGUENS A. G. Locational structure of archaeological undenground storage pits in Northwest Córdoba, Argentina. Revista do Museu de Arqueologia e Etnologia, S. Paulo, 3: 17-33, 1993.

minimum and maximum diameters from 40 to 90 $\mathrm{cm}$ (Fig. 3). They are identified as structured sets or clusterings delimited by the surface concentration of reddish burned earth rings arranged at different places on the site (Fig. 4). For this study we chose one of these groups composed of 112 units. Internally each feature is filled with clear brown aeolian sediments, mixed with ash and charcoal at the bottom, that compose nearly its third part. They have no recognizable base, and the ashy sediments gradually menge into the "loessic" matrix of the site. We excavated ten of these features in order to ascertain their contents and to infer their function. Charcoal, unidentifiable charred seeds and, in one feature, rodentia bones were recovered (Fig. 5).

On the basis of the ecofactual contents, pollen analysis and checking against ethnohistorical sources (Diaz et al., 1987; Laguens and Bonnin, 1987b) we concluded that their main function was seed storage. These seeds would have been a product of the gathering of algarrobo (Prosopis sp.) (the local mesquite), a very abundant species at that time in the Copacabana basin (Bonnin et

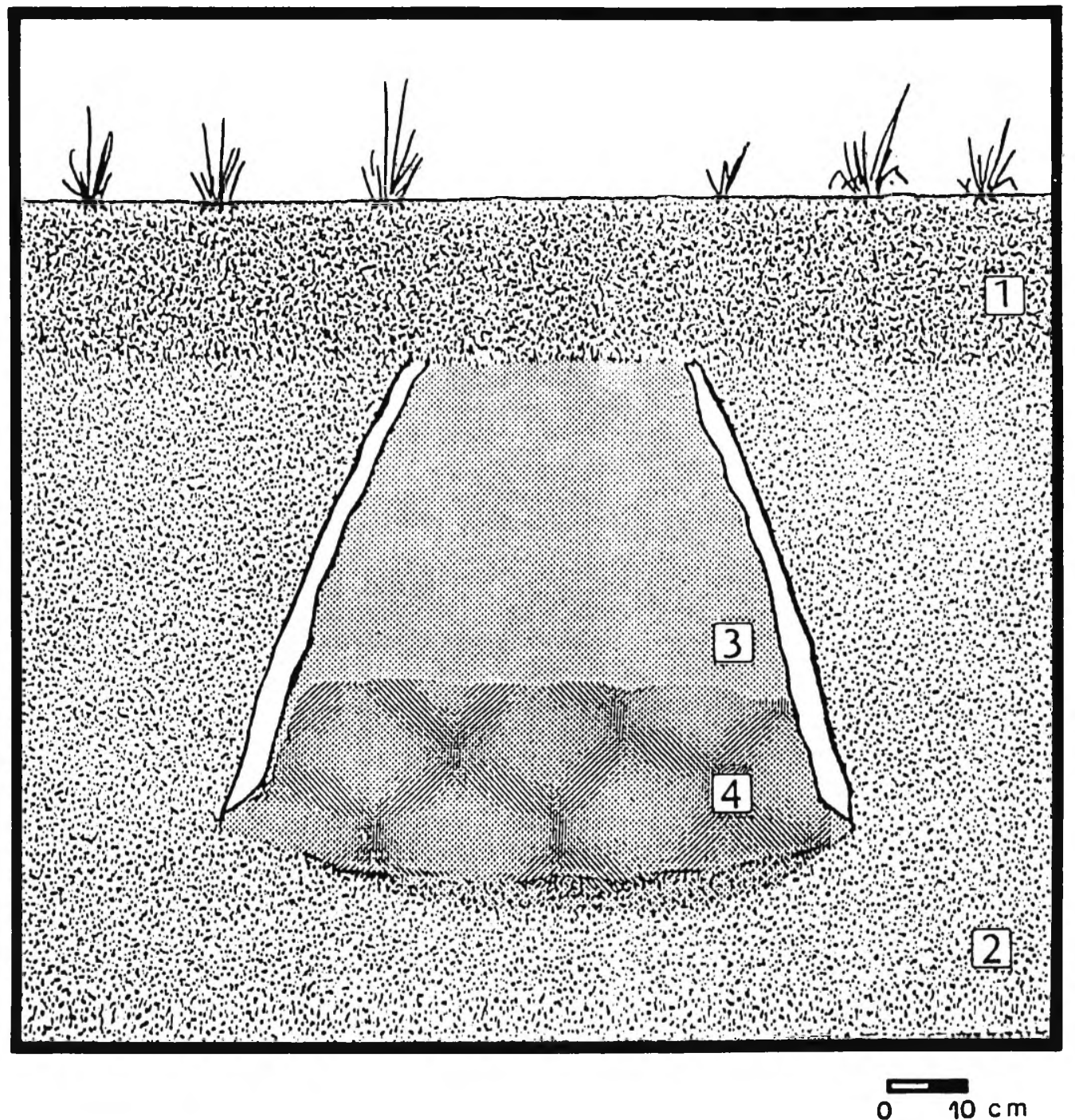

Fig. 3 - Transverse section of a storage pit. 1: actual humus; 2: alluvial matrix; 3: brownish aeolian sediments; 4: gray ashy sediments. 
LAGUENS A. G. Locational structure of archaeological underground storage pits in Northwest Córdoba, Argentina. Revista do Museu de Arqueologia e Etnologia. S. Paulo, 3: 17-33, 1993.

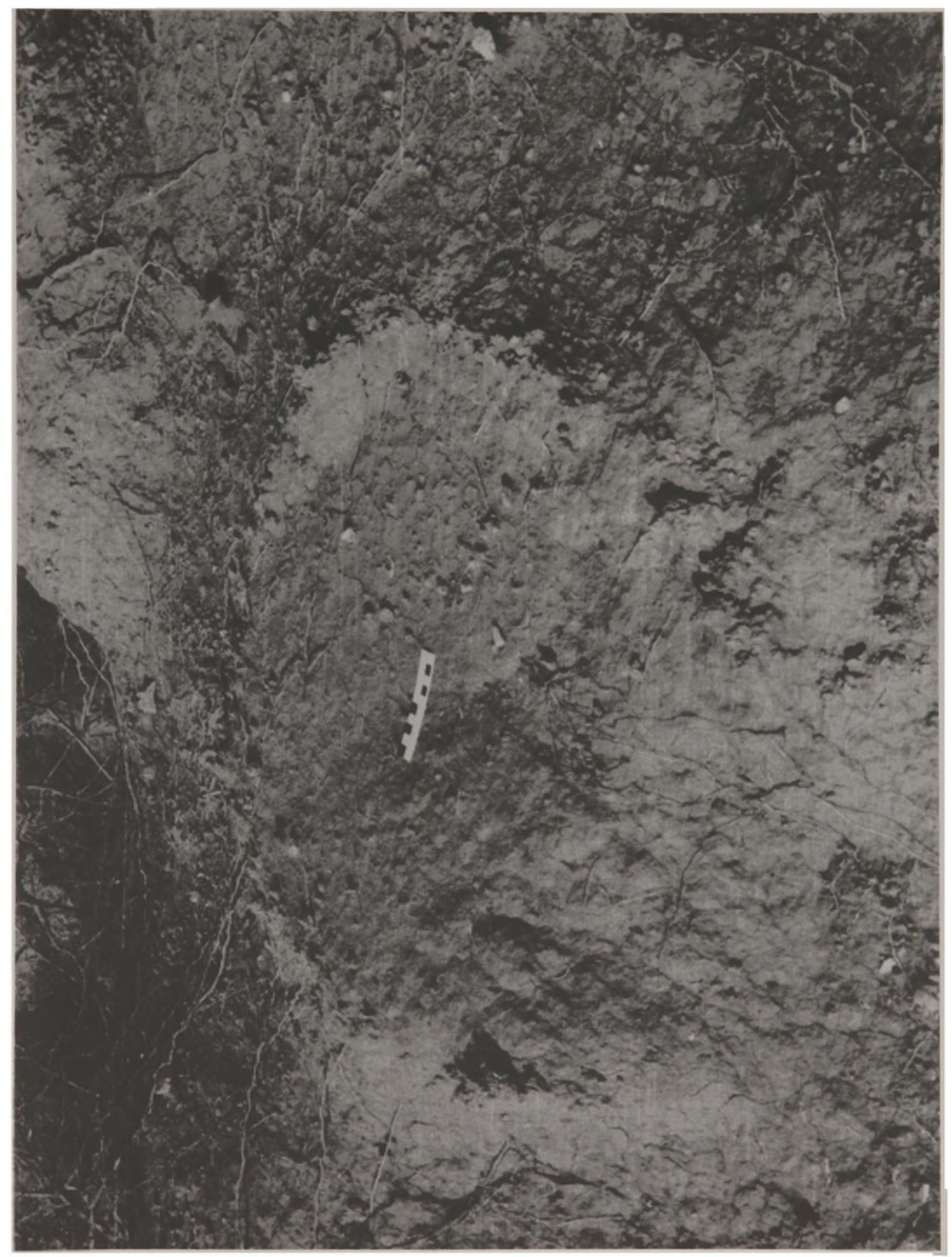

Fig. 4 - Storage pit prior to excavation. 


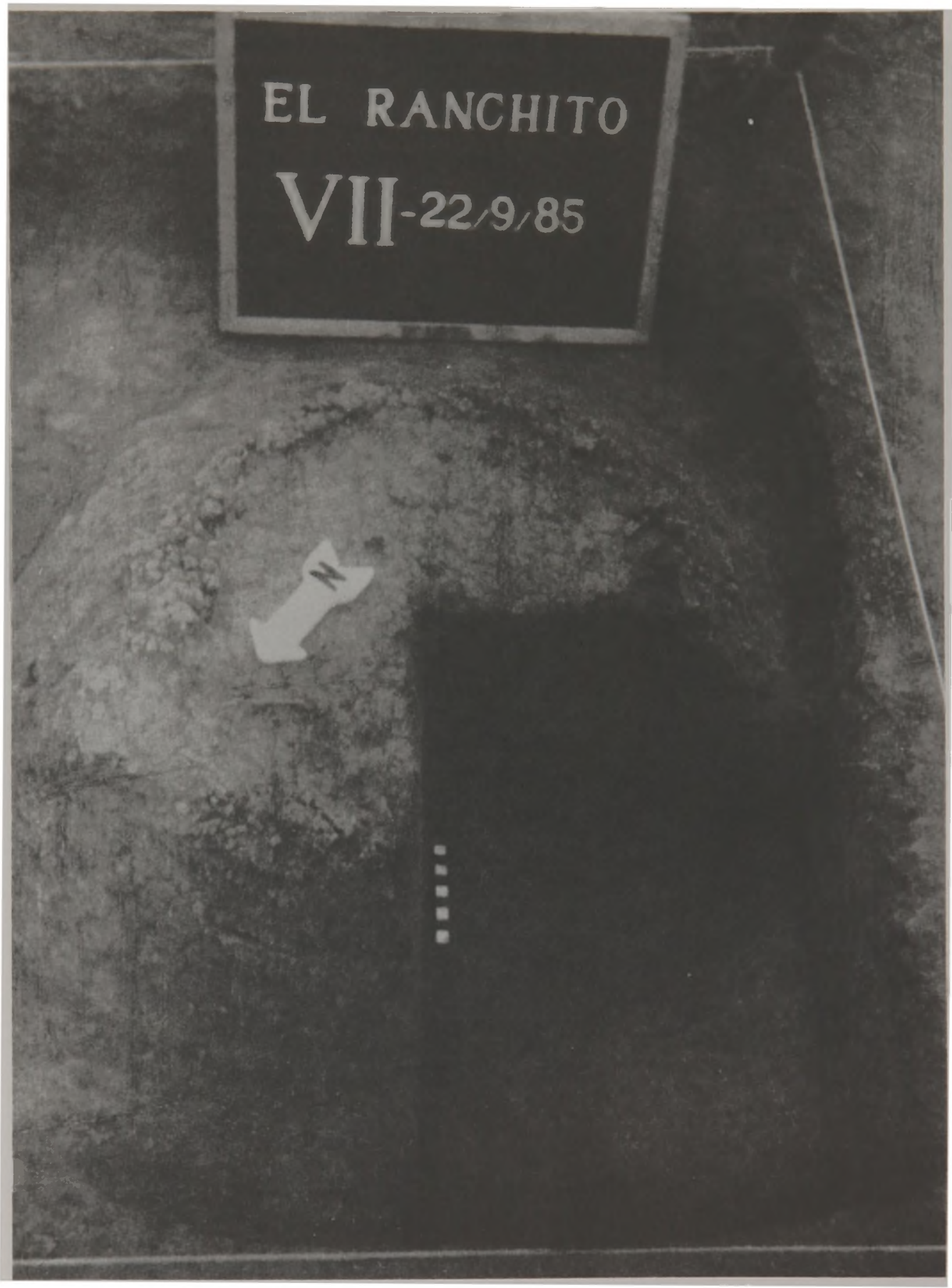

Fig. 5 - One of the excovated features. 
al., 1987). This was confirmed by Spanish documents of 16 th and 17 th centuries where the economic practices of the Indians of NW Córdoba are described. There is almost no description of that time about the life style of the Indians that does not mention the algarrobo as a staple. For example, a clergyman in 1594 said that they used to collect large quantities of algarroba and to store them at big deposits:

“...también se sustentan de grandisima suma de algarroba, la cual cogen por los campos todos los años al tiempo que madura y hacen della grandes depósitos; ...pasan sus necesidades con esta algarroba..." (Translation: they also sustain of large amount of algarroba, which they collect every year across the fields as it ripens and make large deposits ...they overcome their necessities with this algarroba..." (Bárzana, 1594).

At other places in the El Ranchito site we distinguished areas with lithic scatterings of various classes, burial areas, and an opal quarry. Dispersed at different points within the site we found low-density ceramic scatterings.

During three of the six field seasons carried out at this site we excavated specific sectors related to the postulated activity areas. The results are published elsewhere (Laguens and Bonnin, 1987b; Laguens, Bonnin and Díaz, 1987). With these data, and others from the whole basin, we advanced an economic model for prehispanic times. In it we stated that resource exploitation and food production was based upon the differential utilization of three contiguous ecological zones through alternative and/or complementary strategies. This resource-exploitation strategy was based on a yearly round cicle making use of the seasonal differences in the animal and vegetal supplies due to the ecozonal gradient at the valley.

One of the main questions rised by the features is whether they were built during a long period through an accumulative process or if there was a steady growing process in a short time. If the first option were true it would be expected to find a random pattern. In the latter case, had the building of those features been planned, their distribution would tend towards a non random pattern, with no significant chronological differences among them.

\section{Nearest-neighbor analys is}

For the spatial analysis we selected the technique of the nearest-neighbor analysis (NNA) (Carr, 1984, 1985; Earle, 1976; Flannery, 1976; Hodder 1972; McNutt, 1981; Pinder, Shimada and Gregory, 1979; Stark and Young, 1981; Washburn, 1974; Whallon, 1974; Zubrow, 1975), which provides an objective description of the randomness of elements in a finite space. Working with this type of analysis we could provide a thorough and unbiased description of the observable patterning of the structures within the site location.

To use this technique we determined the following field measures: diameter of each structure and distance to all surrounding structures from center to center. From these we established the shortest distance for the nearest neighbor. In order to provide a distribution map of the grouping each radius angle was drawn with respect to magnetic north (Fig. 6). In addition, we calculated the area covered by the structures.

Usually, application of this method has been done in areas larger than the one considered here. But, in spite of our scale, we also found disturbances in the measures introduced by features lying outside the delimited area, known as the boundary effect. To avoid this problem we chose McNutt's proposal (McNutt, 1981), which includes a series of solutions for different area shapes. This way, selecting the formula for the best suitable geometric shape in concordance with the study area, the effect introduced by items with their actual first nearest neighbor outside the chosen area boundaries can be calculated.

Various shapes and surface areas were tested for standarizing a definitive geometric frame and area interval. This was done to minimize the effect of the introduced variation using a geometric shape without knowing a priori which would be the best for the case study. Doing this we expected that when index values (ratio between number of items and nearest neighbor distances), remained approximately constant, in spite of the variation in size and shape, it would mean we had found the most appropiate one. For this reason we applied a simple correlation analysis between different sizes of square and rectangular shapes and NN statistic values for each one of them. We selected only these two shapes because they were the most similar ones to the 


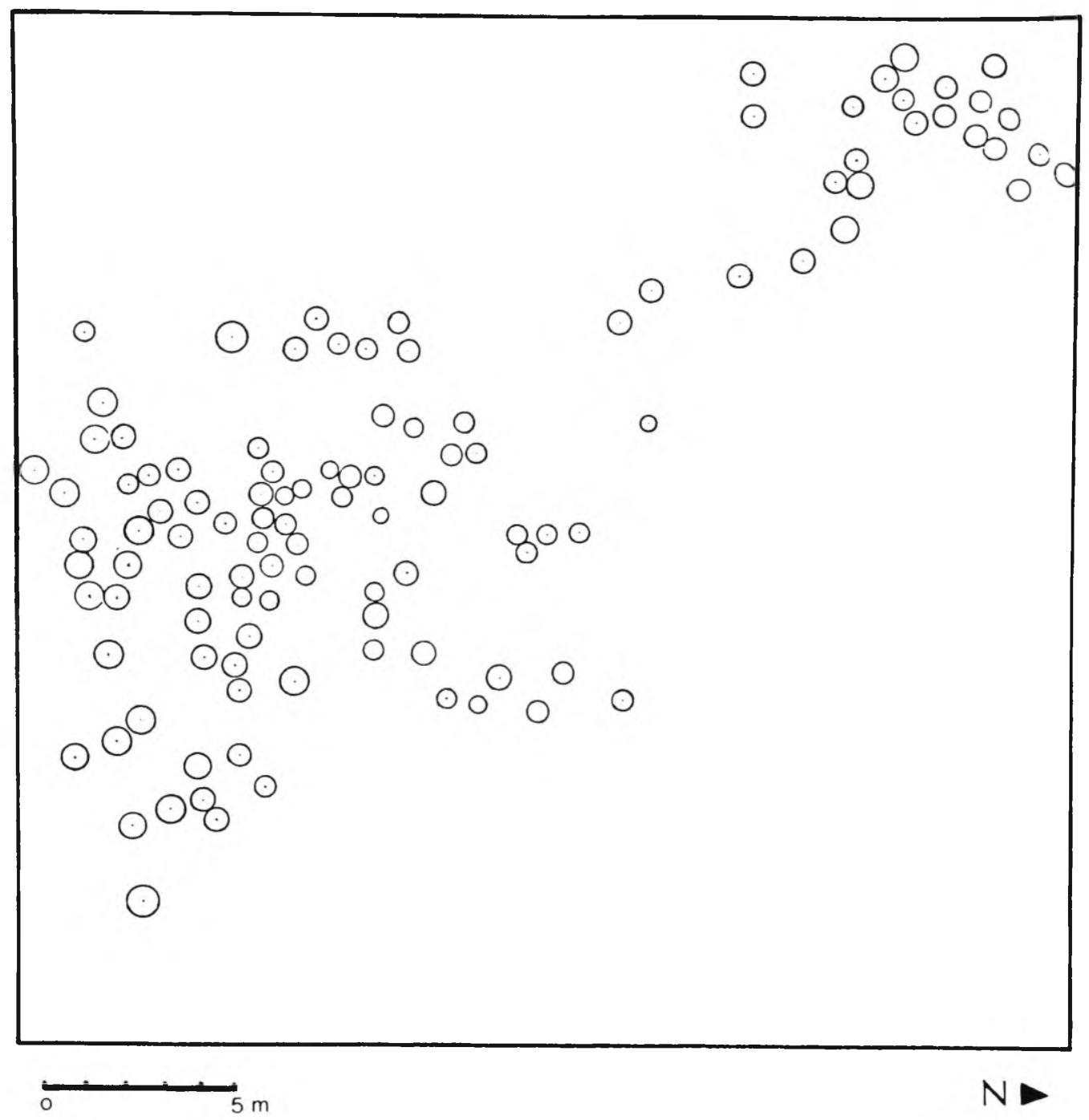

Fig. 6 - Distribution map of feature grouping $B 2$.

natural distribution of the selected sample, including more features and leaving less outside the boundaries than other shapes such as a circumference, a triangle or another polygon.

The largest area we considered first was a square of $26 \mathrm{~m} \times 26 \mathrm{~m}$; then a grid of halfrectangles was superimposed at decreasing intervals of 2 meters (Fig. 7A). Second, we drew another grid, but with concentric squares, also at regular intervals of 2 meters (Fig. 7B). The same was done with a rectangular grid. We consider that both designs satisfied the technical requirement of selecting an area for investigation that lies well within the total area covered by the entire population (Clark and Evans, 1954:450). Following Pinder, Shimada, and Gregory (1979:434) we initially selected the concentric square shape for the analysis since they support that predictions of the expected average distance can only be regard as truly accurate when study areas are square. The rectangular situation increases the number of points likely to be 


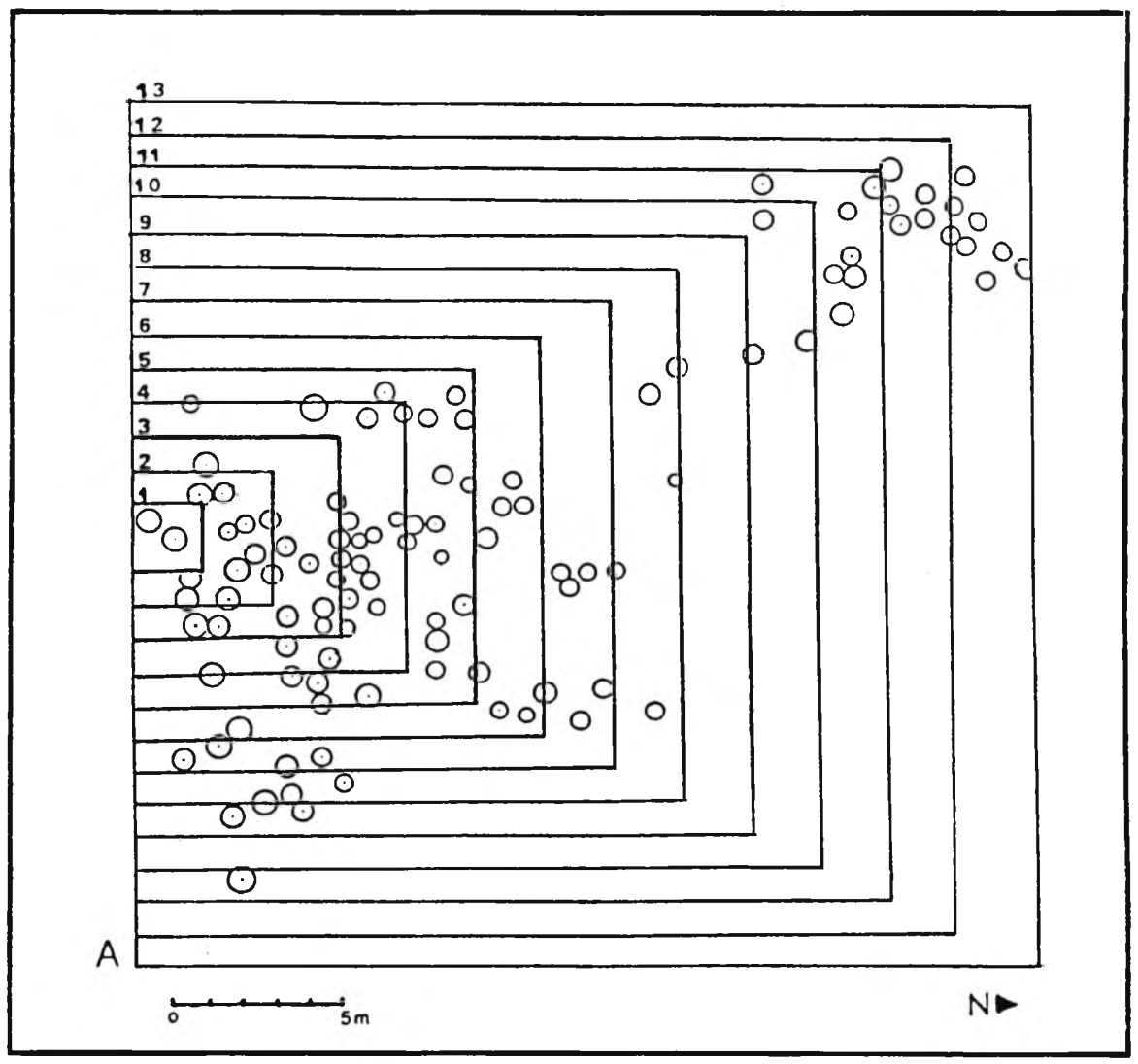

Fig. $7 A$ - Superimposed grids at feature grouping B2: semi-rectangle grid;

separated from "natural" nearest neighbors outside the boundary, with an inevitable addition to the boundary effect.

The problem with the square area was that the pits' distribution tend to be rectangular and there is included much area that contains no features at all (the NE and SW quadrants in Fig. 7B). This would artificially increase the area size, which in turn would artificially decrease the density computation. Then, in order to correct the boundary effects in rectangular areas we applied McNutt's formula for this shape (McNutt, 1981: 591) and also for a series of concentric (Fig. 8) and eccentric rectangles with $2 \mathrm{~m}$ intervals between them.

In Fig. 9 we reproduce the graphics of the correlation analysis between the number of pits and the nearest neighbor statistics used for selecting the more suitable rectangular area design, eccentric or concentric. It is seen that when pit population in concentric grid reaches 30 items (black points) it gets a constant slope. The eccentric design has a more irregular contour until the population reaches 38 items. In other words, that means that concentric grid system has a more descriptive and accurate potentiality. 


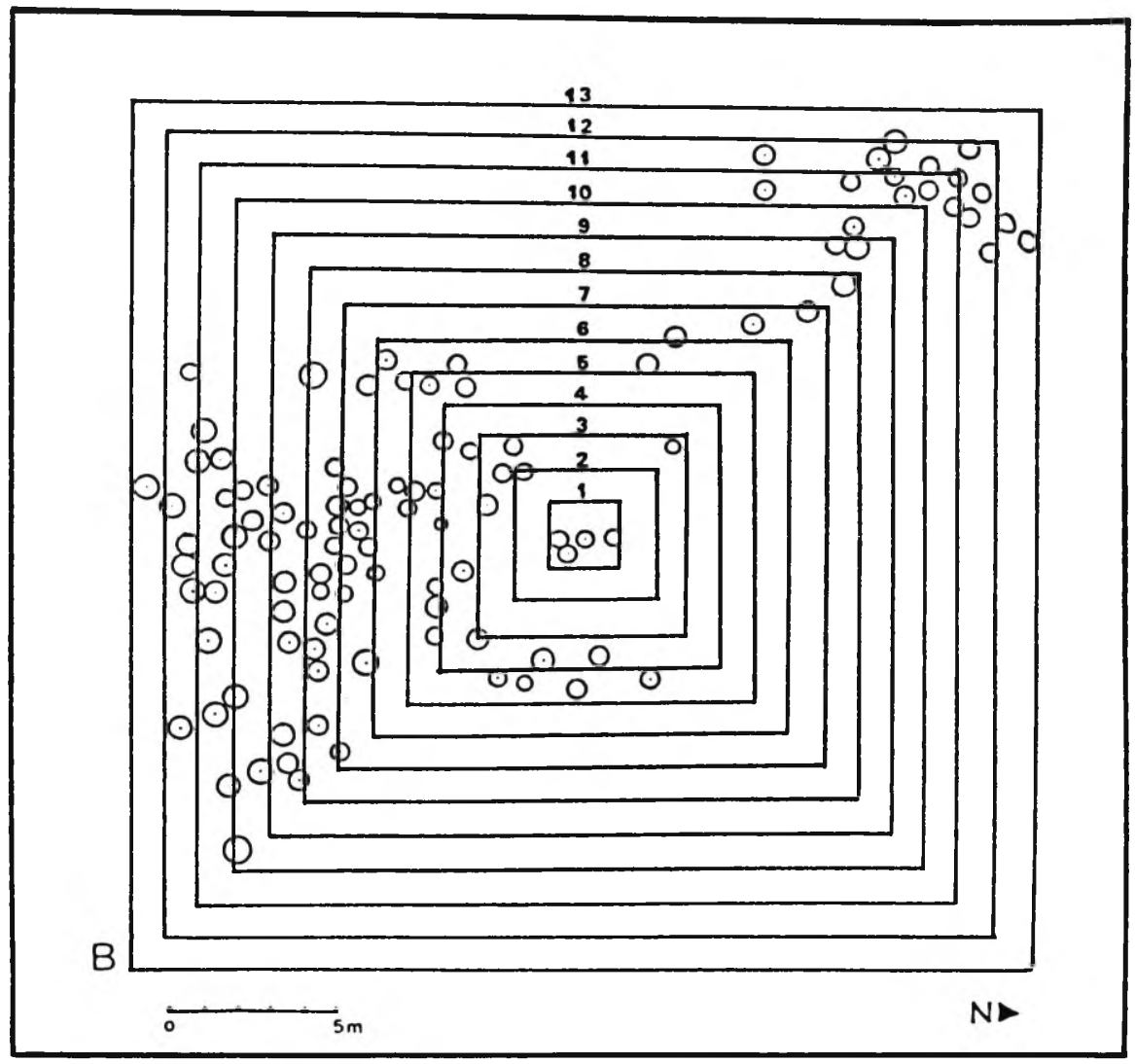

Fig. $7 B$ - Superimposed grids at feature grouping B2: concentric squares grid.

\section{Results}

The final results for the NN statistics analysis of the rectangular area are shown in Table 1. The value for the major area (510 sq $\mathrm{m}$ ) of the grouping of pits with the largest inclusion of features (112 items) was of $R_{\mathbf{n}}=0,79$. This suggests a distribution pattern close to randomness.

According to Clark and Evans (1954:447), the ratio $R$ can then be used as a measure of the degree to which an observed distribution approaches or departs from random expectation. In a random distribution, $\mathrm{R}$ will be equal to 1 ; under conditions of maximum aggregation, $R$ will be equal to 0 ; and under conditions of maximum spacing, the mean distance to nearest neighbor will be maximized and will have the value $R=2.1491$.

In order to assess the statistical significance of the pits' arrangement departure from a random pattern, two tests of significance were carried out. The first one, using a C ratio, (Carr, 1984:155), yielded a significant clustering at 0.05 level of significance $(C=-111$ for $z= \pm 0.3531)$. The second test consisted of a $\mathrm{X}^{2}$ statistic converted to a standard normal variate comparing the result to normal tables, given the large number of items. This procedure also yielded a significant clustering at 0.05 level of significance $(S=-6.37$ for 112 items).

From Table 1, and comparing the data with 


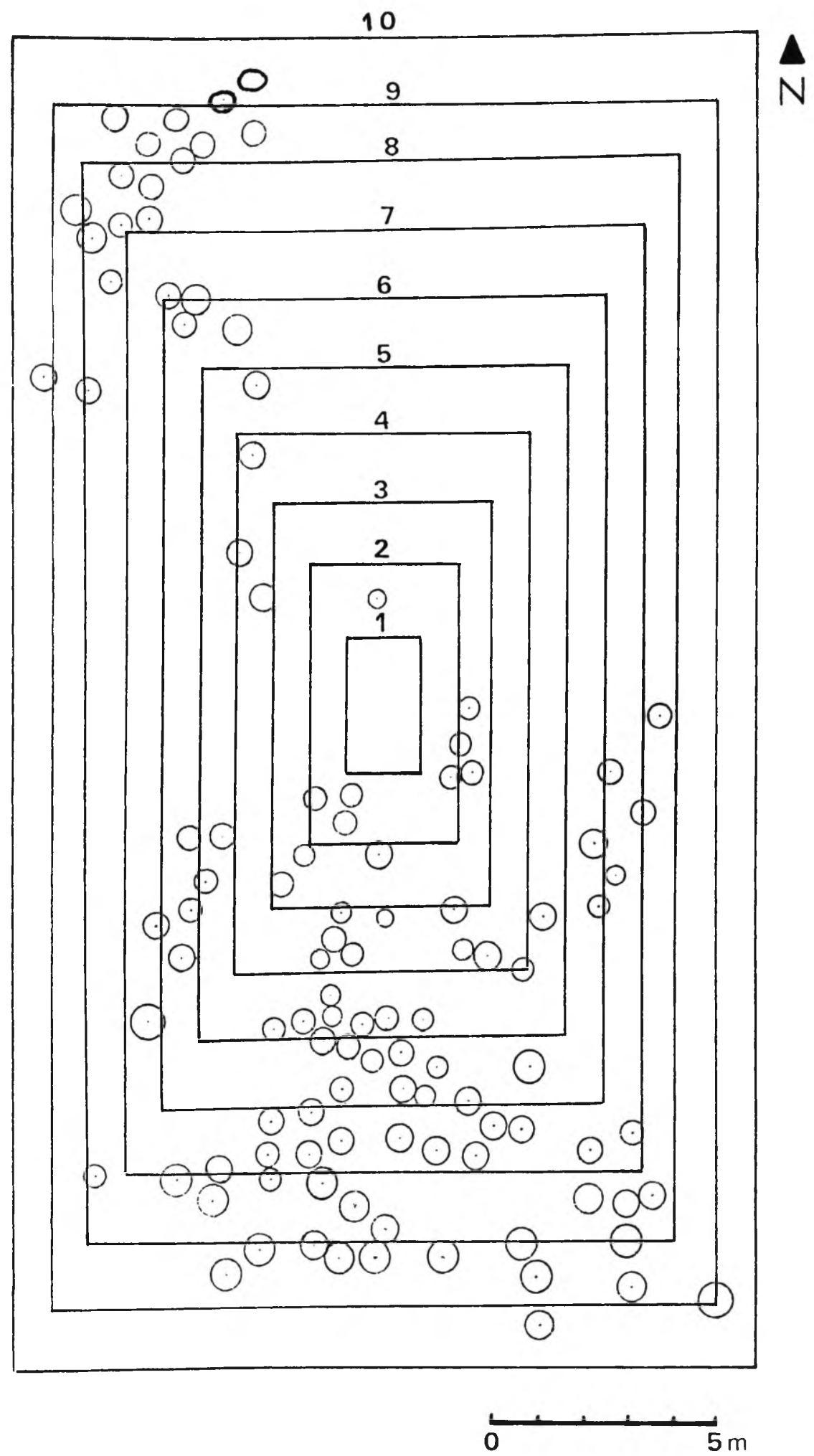

Fig. 8 - Superimposed grid of concentric rectangles at feature grouping $B_{2}$. 


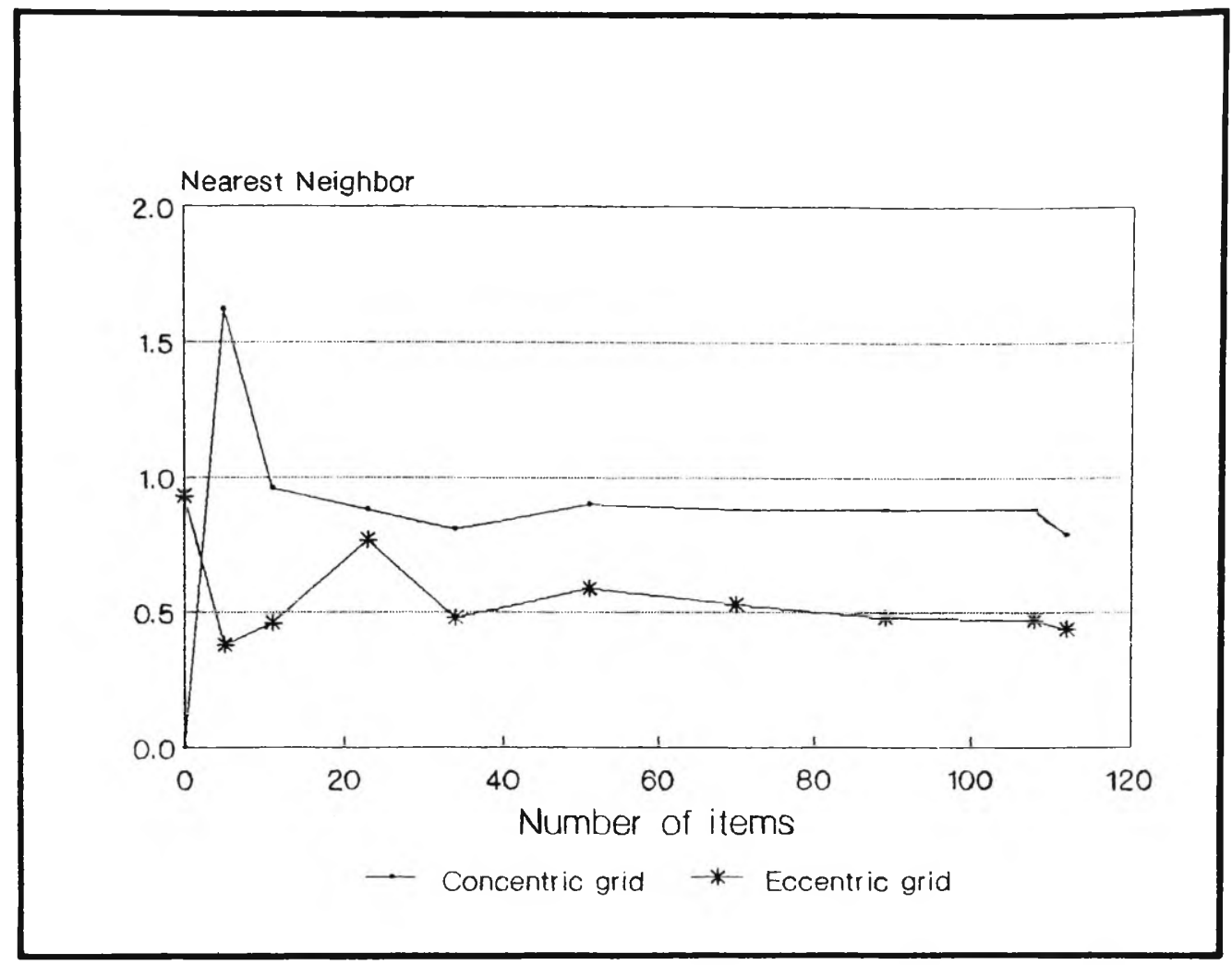

Fig. 9 - Simple correlation analysis between number of features and nearest neighbor statistic values for concentric rectangular grid. $n$ : number of pits; $\boldsymbol{R}_{\boldsymbol{n}}$ : nearest neighbor values.

the distribution map in Figure 6, we can assume that the location of the features within the major area is at random, since all values are less than 1.00. It seems as if the pattern were beginning to slightly aggregate as it increases the number of items and the area size, but the tendency is not significant.

\section{Final considerations}

From our data we conclude that, at an intrasite scale, the features present a non-random grouping. Within groupings, a random distribution is recorded.

We are working with a set of features that are undoubtely in situ, which means that, in terms of its formal structure and spatial distribution, they constitute a system without change, that is, there is a coincidence between their construction, use and abandon contexts (Schiffer, 1972). But we can not validate the same argumentation for its containing or for the various functions they would have had.

We postulate that the excavation in the past of each of the three groups of contiguous underground features represent intra-settlement activity areas, conforming nowadays archaeological monothetic groupings randomly displayed. Thus it can be assumed that there was no previous planning or design in the allocation of each feature within the activity areas.

The fact that they are found randomly displayed within the groupings raises the dilemma 
Table 1. Results of nearest neighbor statistics for feature grouping 2 using the concentric rectangular grid. $r_{i}=$ sum of linear distance between nearest neighbors; $d_{o b}=$ observed average distance; $d_{\text {ran }}=$ expected average distance; $R_{n}=$ nearest neighbor statistic.

\begin{tabular}{ccccccc}
\hline Rectang & $\begin{array}{c}\text { area } \\
\text { sq } \mathrm{m}\end{array}$ & $\begin{array}{c}\mathrm{nr} \text { of } \\
\text { items }\end{array}$ & $\mathrm{r}$ & $\mathrm{d}$ ob & $\mathrm{d}_{\text {ran }}$ & $\mathrm{R}_{\mathrm{n}}$ \\
\hline 1 & 5.1 & 0 & - & - & - & - \\
2 & 17.4 & 5 & 10.30 & 2.06 & 1.27 & 1.62 \\
3 & 45.9 & 11 & 12.80 & 1.16 & 1.20 & 0.96 \\
4 & 81.6 & 23 & 21.18 & 0.92 & 1.04 & 0.88 \\
5 & 127.5 & 34 & 29.98 & 0.88 & 1.04 & 0.81 \\
6 & 183.6 & 51 & 46.16 & 0.90 & 1.00 & 0.90 \\
7 & 249.9 & 70 & 61.76 & 0.88 & 0.99 & 0.88 \\
8 & 326.4 & 89 & 77.96 & 0.88 & 1.00 & 0.88 \\
9 & 413.1 & 108 & 94.61 & 0.88 & 1.01 & 0.88 \\
10 & 510.0 & 112 & 97.86 & 0.87 & 1.10 & 0.79 \\
\hline
\end{tabular}

of whether they were built through an accumulative process or else there was a steady growing process in a short time.

The same kind of features are found through a vast area comprising parts of four states of central Argentina (North Córdoba, San Luis and Santa $\mathrm{Fe}$, and South Santiago del Estero). At Santa $\mathrm{Fe}$, approximately $500 \mathrm{~km}$ southeast from $\mathrm{El}$ Ranchito, there is a radiocarbon date of $2000 \pm$ 100 years B.P. for an habitation level of a site where underground burned earth pits were found (Ceruti, 1988). At Santiago del Estero, 300 km north, these are found in association with ceramics belonging to the Early Period (ca. 0-500 A.D.) (op.cit.; Togo per.com.). Everywhere they have the same morphological characteristics, although they differ in the cultural context and in the number of pits found together. Usually, small groups of no more than a dozen pits, often four or five per site, are recorded. No other site is known where these features were recorded in groupings with such a very high concentration as in El Ranchito.

May be that El Ranchito were a special purpose site within the organization of settlement space at the Copacabana basin, where they were held periodic meetings of people coming from other sites, involved in ritual or seasonal activities, such as gathering of algarroba and other vegetal stuffs. This can be assumed taking in account ethnohistorical data which speak of gathering in common by many peoples at the beginning of the summer:

"...que en las juntas que estos indios tienen es costumbre llamarse unos pueblos a otros para la guerra, cazas o para comer aunque estén lejos de otros.." (AHC 1587) (Translation: it is a custom of these indians to call one each other in their meetings for war, hunting or eating, altough they are far away)

“...alli hacian los bárbaros sus aprovisiones de espigas ... para la próxima estación 
invernal y al calor del zumo de éstas y de los frutos de molle, chañar y de mistol, celebraban sus lloros, borracheras y danzas." (Cabrera 1931) (Translation: there made the barbarians their glean supply for the next winter season and under its hot juice and the molle, chanar and mistol fruits, they celebrate their weepings, drunken feasts and dances)

If this site was in fact for special purposes, holding these periodical meetings that jointed many people from different sites, we could explain the random aggregation of storage pits as a gradual process, due to the periodic reiteration of the same activities at the same places. This could also explain why there are so many pits at El Ranchito in contrast with other sites of the region. But this testing would still have to be confirmed with more datings.

With the data at hand this pattern could also be explained in other terms if we consider the storage strategy in underground pits as an old tradition, with a demonstrable continuity in their formal properties through time, perhaps due to their efficiency as storage facilities. In the whole dispersion area already mentioned this tradition is related to the exploitation of leguminous forest in an unstable environment, as it is in the Chaco (Cabrera, 1976). However, in the 16th century, people living at $\mathrm{El}$ Ranchito for some reason reinforced that strategy by building many more storage pits.

In terms of adaptative technology, building a storage pit could be seen as a microstrategy. If this particular strategy is multiplied by hundreds building three large sets, it becomes in what Clarke called a minimax solution: a series of similar strategies aiming to solve a specific kind of competitive and even conflictive environmental problem. These problems become competitive and conflictive as they interact with cultural systems, promoting social and economic stresses within the human group. In order to counteract these strains there ought to be instrumented solutions (Clarke, 1978). The question we pose then is, What were the problems that prompted the building of these storage facilities in such a great quantity? For us, this strategy was strengthened in response to some stress situation and to adapt to new circumstances they were bearing.

During 16th century there occur two main classes of problems affecting the people living at Copacabana basin. The first could be understood as an endogenous problem of the Indian system, while the second one could be understood as an external or exogenous problem, input to the system by the Spanish Conquest.

In the first case, based on a carrying capacity analysis of the region and demographic analysis for the period 1500-1700 A.D. we concluded that the population of the valley had reached a level that allows us to speak of demographic stress, taking into account the environmental supply of the region and their technological complexity (Laguens, 1990). For that period we determined a mean population density of 9,27 inhabitants per square kilometer (7,5 inhabitants for ca. 800 square kilometer of the whole basin). Their main vegetable subsistence stuffs were maize and algarroba, both very important nutrients of high vitamin, protein and caloric content, but with a characteristic unstable productivity, too much dependent on environmental conditions. Typically, even nowadays, a good year for maize growing is a bad one for algarroba gathering. Thus, we are faced with a very high population pressure and fluctuating resources.

In addition, it must be borne in mind that it has been demonstrated that during this time there occurred environmental fluctuations at Andean South America (Cardich, 1980; D'Antoni, 1980; Markgraf, 1984) that perhaps would have had an influence in Córdoba.

This problem surely demanded an appropriate solution. The strategy then would be to store in the underground burned earth features. If we estimate the pits' carrying capacity of the three intra-site groupings (each pit has a mean volume of 140 kilograms of grains and there are recorded aproximately 350 pits) we can certainly conclude that to stregthen this technology was clearly an adaptative strategy with a considerable labor investment that would have needed a powerful justification.

In respect with the external problem superposed to the system, the Spanish Conquest from 1573 A.D. on, compelled the Indians to pay taxes and imposed restrictions on their access to diverse ecological environments and zones of the basin. The simultaneous access to different milieus was the basis of the aboriginal resource exploitation strategy during pre-conquest times (Laguens y 
Bonnin, 1987b). This could be clearly seen through the analysis of the faunal remains recovered at the site: they include species belonging to different environments such as Mazama guazoubira, a small deer living exclusively in the forested hills upstream Copacabana river; and Lama guconicoe (guanaco), Ozotocerus bezoarticus, a larger deer, and Rhea americana (ñandú), the American ostrich, all typical species of open landscape with savannas and marshes, such as the landscape downstream the river.

This exploitative mechanism was compulsorily modified when the Spanish Crown began granting land to the conquerors (Diaz et al., 1987) and the Indians could no longer go too far away from their site range for hunting or gathering. Furthermore, we have to take in account that males between 18 and 50 years had to begin paying a tax twice a year. This tax could be paid with stuffs, such as cotton or algarroba, and was more or less equivalent to an hectare of maize or the food supply neccessary to mantain 0,56 person during a year (ca. 500,000 kcal) (Bonnin and Laguens, 1991). This way there was not only a forced reduction of the Indian habitat but also more extractive pressure with no new niche to exploit until the indigenous incorporation of European vegetal and animal species.

In summary, faced with population pressure, new cultural conditions and when complementarity was no longer possible, building more underground burned earth features at a site in order to store larger amounts of the available food supplies could have continued as a survival strategy.

It still remain to be answered from this perspective why these features are displayed with a random pattern, involving no previous design of their distribution, as if they were built without any planned order.

We think that the reinforcement of the storage capacity has to be seen in the context of a temporary shift of the cultural system toward expedient technologies, in order to counterbalance the various stresses bearing upon it. This does not mean that building more storage facilities was an expedient strategy since storage pits are essentialy curated artifacts but their distribution could be seen as a rapid solution with the least time and energy expenditure in front of a crisis situation.

At many sites in the valley during the first century after the Spanish Conquest it is recorded a shift both in lithics and ceramics from a conservative technology towards a more expedient one (Laguens, 1992). In lithhe technology, this process is mainly seen in reduction procedures with increments in the amount of lithic debris, unretouched utilized flakes, and percentage of unifacial percussion and retouch. In ceramic technology, there is a clear lowering in paste quality, mainly seen as less shock and thermal resistance, the occurrence of varying sizes and shapes in non-plastic inclusions, and increase in the percentage of incomplete firing.

This change in the overall technological strategy can be understood as a minimax solution that tended towards a minimization of risk in front of unbalanced inputs to the indigenous system.

We are not still in a position to support exclusively the latter reasoning. Yet we consider that there are more concurring facts that render this explanation more covering than the other one in respect to the locational structure found. We do not discard the first option, the gradual growing of the storage areas, and we even think that both processes could have happened, one prior to the Spanish Conquest and the other under the new cultural conditions imposed by the Spaniards.

\section{Acknowledgments}

I would to thank Dr. Mebus Geyh, Niedersächsiches Landesamt für Bodenforschung of Hannover, for the radiocarbon dating of the charcoal sample of one of the storage pits. Dr. Charles McNutt made very helpful comments which actually tought me about NNA, and Mirta Bonnin and Luis Orquera revised an earlier version of this paper making clever suggestions. I am very thankful for all of them. 
LAGUENS A. G. Locational structure of archaeological underground storage pits in Northwest Córdoba, Argentina. Revista do Museu de Arqueologia e Etnologia, S. Paulo, 3: 17-33, 1993.

\begin{abstract}
LAGUENS A. G. Locational structure of archaeological underground storage pits in Northwest Córdoba, Argentina. Revista do Museu de Arqueologia e Etnologia, S. Paulo, 3: 17-33, 1993.
\end{abstract}

ABSTRACT: This report gives the results of an intra-site spatial analysis of underground burned-earth features at a prehispanic site at central Argentina: El Ranchito, dated between 1000 B.C. and A.C. 1600 . The features are locally known as botijas and they are recorded at the site as three concentration areas displaying a non-random distribution including between 100 and 120 botijas each area. Within them, a random distribution is recorded.

The study was carried out in order to assess its intentional localization as storage areas within the site. It is postulated that this storaging strategy was adopted as a solution for a number of concurrent problems, primarily expanding population and environmental fluctuations. During the Spanish Conquest (16th century) this strategy would also have been implemented as response to cultural and economic shock prompted by the conquerors' appropriation of land and resources.

UNITERMS: Spatial analysis - Storage sites - Argentinian archaeology.

\title{
References
}

ACH (Archivo Histórico de Córdoba) (1587) Escribanía 1, Legajo 1, Expediente 2, foja 1. Córdoba, Argentina.

BÁRZANA, P.A. (1594) Carta del P. Alonso de Bárzana, de la Compañía de Jesús, al P. Juan Sebastián, su Provincial. Relaciones Geográficas de Indias. España, Min. de Fomento, pp. LII-LXVI, Madrid, 1885.

BINFORD, L. R. (1965) Archaeological Systematics and the Study of Culture Process. American Antiquity, 31: 203-210.

- (1977) Introduction in Lewis R. Binford (Ed.) For Theory Building in Archaeology. Academic Press, New York : 1-10.

CABRERA, A. L. (1976) Regiones fitogeográficas argentinas. Enciclopledia Argentina de Agricultura y Jardineria, vol. 2. Editorial Acme, Buenos Aires.

CABRERA, P. (1931) Córdoba del Tucumán prehispana y protohistórica. Rev. Univ. Nac. Córdoba, año XVIII, No 7 . 8. Córdoba, Argentina.

CARDICH, A. R. (1980) Origen del hombre y de la cultura andinos. Juan Mejia Baca (Ed.) Historia del Perú, Vol. 1. Lima, Perú: 31-156.

CARR, C. (1984) The Nature of Organization of Intrasite Archaeological Records and Spatial Analytic Approache to their Investigation. Michael B. Schiffer. (Ed.)Advances in Archaeological Method and Theory. Academic Press, New York: 103-222.

- (1985a) Perspective and Basic Definitions. Christopher
Carr (Ed.) For Concordance in Archaeological Analysis. Westport Publishers, Kansas City: 1-17.

- (1985b) Alternative Models, Alternative Techniques: Variable Approaches to Intrasite Spatial Analysis. Christopher Carr (Ed.) For Concordance in Archaeological Analysis. Westport Publishers, Kansas City: 302-473.

CERUTI, C. N. (in press) "Modificación ambiental y adaptación cultural en la Cuenca del Paraná Medio. Publicaciones del CIFFYH, Córdoba.

CLARK, P. J; FRANCIS, C. E. (1954) Distance to Nearest Neighbor as a Measure of Spatial Relationships in Populations. Ecology, 35: 445-453.

CLARKE, D. L. (1972) Spatial Information in Archaeology David L. Clarke (Ed.) Spatial Archaeology. Accademic Press, London: 1-32.

- . (1978) Analytical Archaeology, 2nd edition (revised by Bob Chapman). Methuen and Co., London.

D'ANTONI, H. L. (1980) Pollen Analysis of Gruta del Indio. Quaternary of South America and Antarctic Penınsula, 1: 83-104.

D'ANTONI, H.L; SOLBRIG, O.T. (1977) Algarrobos in South American Cultures. Past and Present. Edward B. Simpson (Ed.) Mesquite. Its biology in two desert ecosystems. Hutchinson and Ross Inc. Strondsburg, Pensylvania, Dowden: 190-199.

DÍAZ, S.; BONNÍN, M.; LAGUENS, A.; PRIETO, M. del R. (1987) Estrategias de explotación de los recursos 
naturales y procesos de cambio de la vegetación en la cuenca del rio Copacabana (Dto. Ischilin, Pcia. de Córdoba) I: mediados del siglo XVI - mediados del siglo XIX. Publicaciones del Instituto de Antropologia (Córdoba), 45: 67-132.

EARLE, T. K. (1976) A Nearest-Neighbor Analysis of Two Formative Settlement Systems. Kent V. Flannery (Ed.) The Early Mesoamerican Village. Academic Press, New York: 196-223.

FLANNERY, K. V. (1976) Linear Stream Patterns and Riverside Settlement Rules. Kent V. Flannery (Ed.) The Early Mesoamerican Village. Academic Press, New York: 173-180.

HODDER, I. (1972) Some New Directions in the Spatial Analysis of Arcaheological Data at the Regional Scale (Macro). David L. Clarke (Ed.) Spatial Archaeology. Academic Press, London: 223-352.

LAGUENS, A. G. (1988) La distinción emic-etic en arqueología. Boletin de Antropologia Americana (Mexico), 17: 133-144.

- . (1990) Estrategias adaptativas pre y post-contacto hispano indigena en los sectores medio y superior de la cuenca del río Copacabana, Provincia de Córdoba. Unpublished report on file, CIFFYH, Universidad Nacional de Córdoba, Córdoba, Argentina.

- (1992) Niveles de eficienca adaptativa pre y post contacto hispano indígena en el sector superior del Valle de Copacabana, Córdoba, Argentina. Unpublished report on file, CONICET, Bs.As., Argentina.

LAGUENS, A. G.; BONNÍN, M. (1987a) Un encuadre teórico para la práctica arqueológica. Ensayo de un método alternativo de trabajo. Publicaciones del Instituto de Antropologia (Córdoba), 45: 15-28.

- (1987b) "Espacio, paisaje y recursos. Estrategias indigenas alternativas y complementarias en la cuenca del río Copabana (Dto. Ischilin, Córdoba, Argentina). Sitio El Ranchito. 1000 a.C.-1600 d.C. Publicaciones Instituto de Antropologia (Córdoba), 45: 159-200.

- (in press) La población indígena en la cuenca del río Copacabana en el siglo XVII. Publicaciones del CIFFYH (Córdoba).
LAGUENS, A. G.; BONNÍN,M.; DÍAZ, S. (1987) Programa Chuña Publicaciones del Instituto de Antropologia (Córdoba) 45: 9-14.

MARKGRAF, V. (1984) Paleoenvironmental History of the Last 10,000 Years in Northwestem Argentina. K. Garleff and H. Stingl (Eds.) Südamerika. Geomorphologie und Paläoökalogie des jüngeren Quartärs. Stuttgart, Zentralblatt für Geologie und Palăontologie, Teil I, Heft 11/12: 1739-1750

McNUTT, C. H. (1981) Nearest Neighbor, Boundary Effect, and the Old Flag Trick: A General Solution. American Antiquity, 46: 571-591.

PINDER, D.; SIMADA, I.; GREGORY, D. (1979) The Nearest Neighbor Statistic: Archaeological Applications and New Developments. American Antiquity, 44: 156165.

SCHIFFER, M. B. (1972) Archaeological Context and Systemic Context. American Antiquity, 37: 156-165.

- (1975) Behavioral Chain Analysis: Activities, Organization, and the Use of Space. Fieldiana Anthropology, 65; Publication 1201, Field Museum of Natural History, Chicago.

- (1976) Behavioral Archaeology. Academic Press, New York.

STARK, B.; YOUNG, D. L. (1981) Linear Nearest Neighbor Analysis. American Antiquity, 46:84-300.

WASHBURN, D.K. (1974) Nearest Neighbor Analysis of Pueblo I-Il Settlement Patterns along the Rio Puerco of the East, New Mexico. American Antiquity, 39: 315-335.

WHALLON, R. (1973) Spatial Analysis of Paleolithic Occupation Areas. Colin A. Renfrew (Ed.) The Explanation of Culture Change: Models in Prehistory Duckworth, London: 114-130.

- (1974) Spatial Analysis of Occupation Floors II: the Application of Nearest Neighbor Analysis. American Antiquity, 39: 16-34.

ZUBROW, E. (1971) Carrying Capacity and Dynamic Equilibrium in the Prehistoric Southwest. American Antiquity, 36: 127-138.

- (1975) Prehistoric Carrying Capacity: A Model. Cummings Publishing Co, Menlo Park, California. 